\title{
Impacts of Madhupur National Park on Local Peoples' Livelihood
}

\author{
M. M. Mian, M. B. Khan and M. A. Baten \\ Department of Environmental Science \\ Bangladesh Agricultural University, Mymensingh
}

\begin{abstract}
In this study, the impact of Madhupur National Park on local peoples' livelihoods was assessed. To find local peoples perception on collaborative natural resources management. This study was conducted from July, 2012 to December, 2012 on two villages named Talki and Sholakuri. Data collection was based on stratified random sample. Stratification was based on park proximity of respondent households that is (inside park) $0 \mathrm{~km}, 0.5 \mathrm{~km}$ distance, $1 \mathrm{~km}$ distance, $1.5 \mathrm{~km}$ distance and $2 \mathrm{~km}$ distance from Madhupur National Park boundary. The five strata were compared with respect to household's natural resource dependency, household's income, income diversification, income level, assets and perception on present management system. Present management system was also discussed to emphasize park management authority contribution on local livelihood. Based on analysis of collected data from two villages it was assumed that the nearest people were more dependent on natural resource of park than far people. The simple correlation coefficient for the distance of household with natural resource dependency was negatively significant. Household average monthly incomes in two villages were approximately same but Talki villagers were 79.25\% depend on park related activity and this dependency decreased with increasing of distance. Present park management system plays an important role to reduce people and park animosity by providing aid and training to the local offensive persons and involve them into park conservation. A trend analysis of decreasing forest offences represented that, the present management system is better than past time and it could be able to reduce people park animosity.
\end{abstract}

Key words: Livelihood, Madhupur National Park, Impact, Income, Management, Forest offences.

\section{Introduction}

Many of the world's protected areas are important not only for their biodiversity, but also for their natural resources that many local people rely on for their livelihoods (Falconer and Arnold, 1989). Many people believe that without the active involvement of local people in park management and increasing economic incentives for their collaboration in conservation, there is little chance for protected areas (PAs) to be conserved and local resources to be sustainably managed. People also argue that the conservation of biodiversity in PAs will be more challenging if local communities are heavily dependent on these areas for energy, nutrition, medicine, and other subsistence needs (Mesozera and Janaki, 2004). In the context of Bangladesh, it is very difficult to involve local people in conservation efforts without providing them with some direct and tangible benefits - either benefits in kind or cash for their involvement (Begum, 2011). Rural people in developing countries depend heavily on natural resources and derive a significant portion of their income and livelihoods from them (Cavendish, 2000). To counteract the negative effects of protected areas, a number of approaches have been formulated to reduce tensions between local communities and protected areas management. Legal extraction of park resources, revenue sharing (for instance of tourist gate fees) and community representation on park management advisory committees (Adams, 2003), to enable benefits of managing protected areas to be realized by both government agencies and local communities (Mugisha, 2002).

National park like Madhupur National Park can provide various goods and services to local communities around it, and therefore contribute to improvement of livelihood, this is true for all protected areas. Parks do not only provide food, medicine, fodder etc to local communities but also parks offer job opportunities, educative programs, training, and other community services (Blom, 2000; Kibirige, 2003).

This study seeks to find the implications of park proximity on local livelihoods in terms of natural resource dependency, livelihood diversification and income distribution; and investigate the local people's attitudes and perceptions on the current management approach of Madhupur National Park.

\section{Methodology}

The study was done based on primary and secondary information. Different methodologies such asquestionnaire interview with local people, Focus Group Discussion (FGD) and Key Informant Interview (KII) and actual observation were used to 


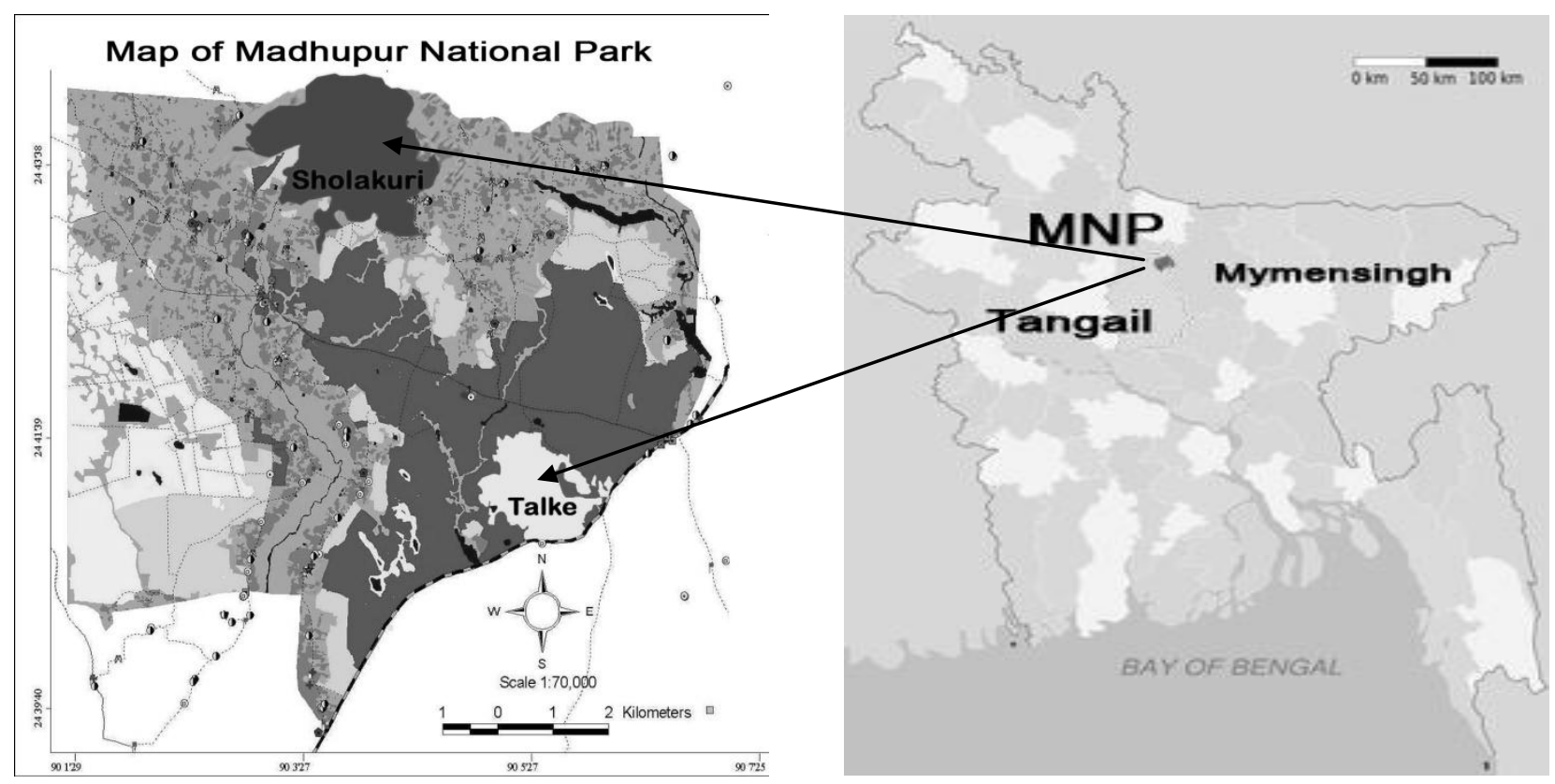

Fig 1. Study area Talki village and Sholakuri village on Madhupur National Park (Begum, 2011).

identify the impacts of park proximity on local peoples livelihood, existing management system and assessing public perception on management. Primary data about livelihood were collected by stratified random sampling. Those strata were distance of villagers houses from Madhupur National Park boundary.

Table 1. Distance of households from Madhupur National Park boundary

\begin{tabular}{|l|c|c|c|c|}
\hline & \multicolumn{4}{|c|}{ Households } \\
\hline & \multicolumn{2}{|c|}{ Talki $(\mathrm{N}=20)$} & \multicolumn{2}{c|}{ Sholakuri $(\mathrm{N}=40)$} \\
\hline Distance & No. & $\%$ & No. & $\%$ \\
\hline Inside $(0 \mathrm{~km})$ & 20 & 100 & 3 & 7.5 \\
\hline $0.5 \mathrm{~km}$ distance & 0 & 0 & 11 & 27.5 \\
\hline $1 \mathrm{~km}$ distance & 0 & 0 & 9 & 22.5 \\
\hline $1.5 \mathrm{~km}$ distance & 0 & 0 & 7 & 17.5 \\
\hline $2 \mathrm{~km}$ distance & 0 & 0 & 10 & 25 \\
\hline
\end{tabular}

Talki village is inside and Sholakuri village is adjacent to Madhupur National Park boundary. The correlation were made between independent variable 'distances of households' with dependent variables 'Household Assets Items Owned, Forest Resource Collection, Households income on park activity and off park activity and Public Opinion About Park Management' to achieved the impacts of park on livelihood.

The secondary data were collected from the management authority of Tangail Forest Division and related literatures. The electronic and web based information were also used for data collection and SPSS-14 and MS Office 2007 were used for data analysis.

\section{Results and Discussion}

\section{Natural resource dependency of local peoples'}

Peoples of Talki and Sholakuri villages were mainly collect wood, fuelwood, fruits and lives, grasses, bamboo and honey from Madhupur National Park. This diagram represents the percentage of villagers on two villages of each forest items category.

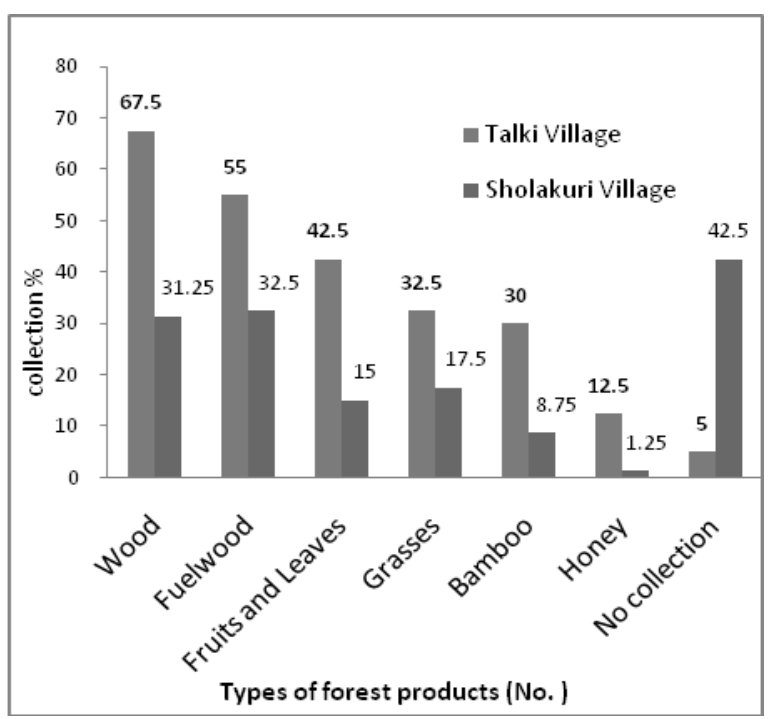

Fig 2. Collection of forest products by two villages 
There two or more items of forest products were collected by the same respondents. Maximum four items and lowest 0 items were collected by respondents. The dependency on forest products were varied on respondents to respondents.

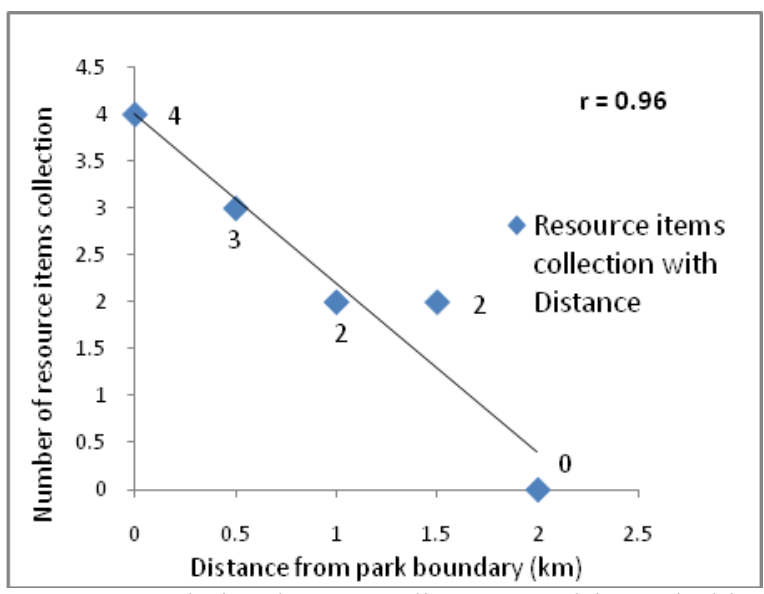

Fig 3. Correlation between distance and households' resource items collection

The simple correlation coefficient value 0.96 represent strong association between distance and forest resource items collection. The curve represents the number of resource items collection were decrease with the increase of distance from park boundary. So the nearest peoples were more dependent on natural resource than far peoples.

\section{Effects of park on households' income}

The average incomes of households in different distance of park boundary were approximately same but their income activity were varied.

Table 2. Average income of households on park activity and off park activity

\begin{tabular}{|c|c|c|c|c|}
\hline \multirow{2}{*}{ Distance } & \multicolumn{4}{|c|}{ Income (Average) } \\
\cline { 2 - 5 } & $\begin{array}{c}\text { Park } \\
\text { activity } \\
\text { (BDT) }\end{array}$ & $\%$ & $\begin{array}{c}\text { Off park } \\
\text { activity } \\
\text { (BDT) }\end{array}$ & $\%$ \\
\hline $0 \mathrm{~km}$ & 3302.02 & 79.25 & 864.65 & 20.75 \\
\hline $0.5 \mathrm{~km}$ & 1912.18 & 54.04 & 1626.5 & 45.96 \\
\hline $1 \mathrm{~km}$ & 1679.20 & 34.18 & 3233.36 & 65.82 \\
\hline $1.5 \mathrm{~km}$ & 264.87 & 6.94 & 3549.39 & 93.06 \\
\hline $2 \mathrm{~km}$ & 61.39 & 1.32 & 4598.23 & 98.68 \\
\hline
\end{tabular}

Above table represent that, the park activity income gradually decreased with the increase of distance of households from park boundary and off park activity income was found to increase with the increase of distance. So because of staying inside Talki villagers has more park activity income than Sholakuri villagers. It represents that the proximity people of park depend on park for their average monthly income than far people of park boundary.

\section{Park contribution on household asset}

Generally six items of assets were owned by the villagers around Madhupur National Park, those were cows, goats, poultry, pigs, forest land and forest products. Each household had one or more items of assets.

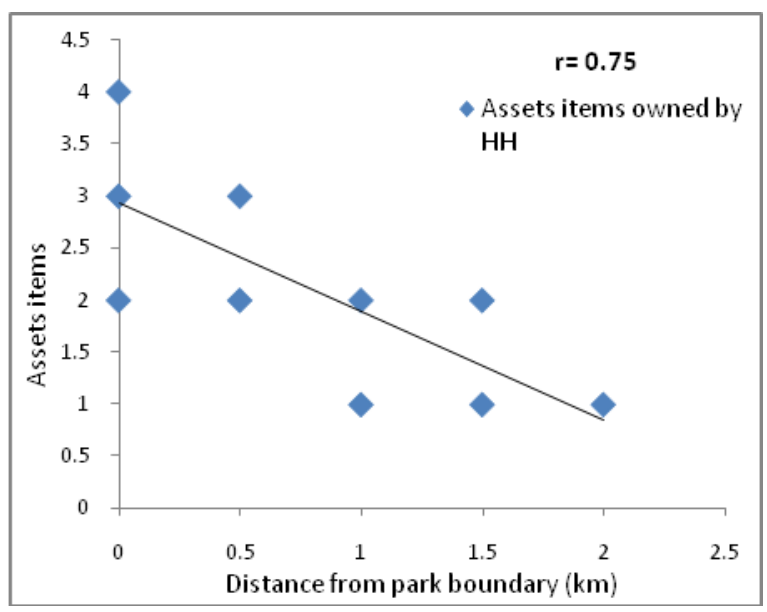

Fig 4. Correlation between distance and households' assets items owned

The simple correlation coefficient value is 0.75 represent strong relations between distance and household assets items owned. Households at $0 \mathrm{~km}$ distance from park boundary were received various aids from park management authority. They use forest products and lad for their daily needed.

\section{Decreasing trend of forest cover area}

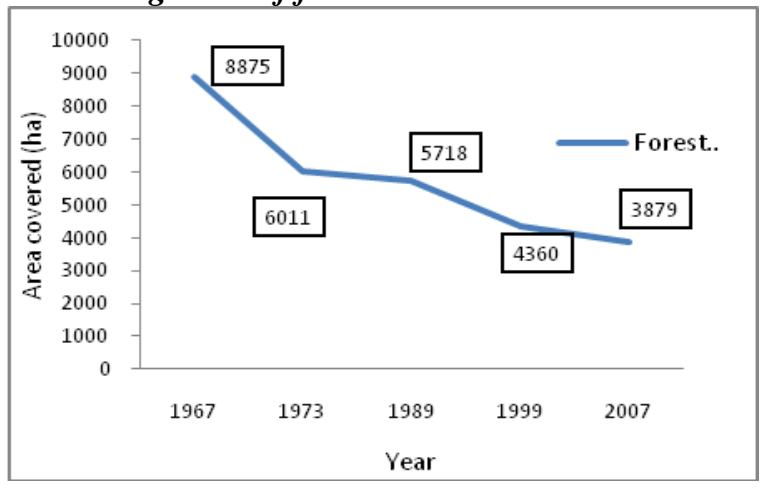

Fig 5. Trend of decreasing forest covers area (CEGIS, 2008)

The people around and inside the Madhupur National Park were dependent on park for their daily needs. The illegal wood traders also influence them for cutting trees. The forest management authority takes 
various strict steps to protect national resource but it made collision between authority and local peoples. Then community forestry established. That is local people use forest land in buffer zone and developed them and protects natural resource.

\section{Forest Offence Scenario on Madhupur National Park}

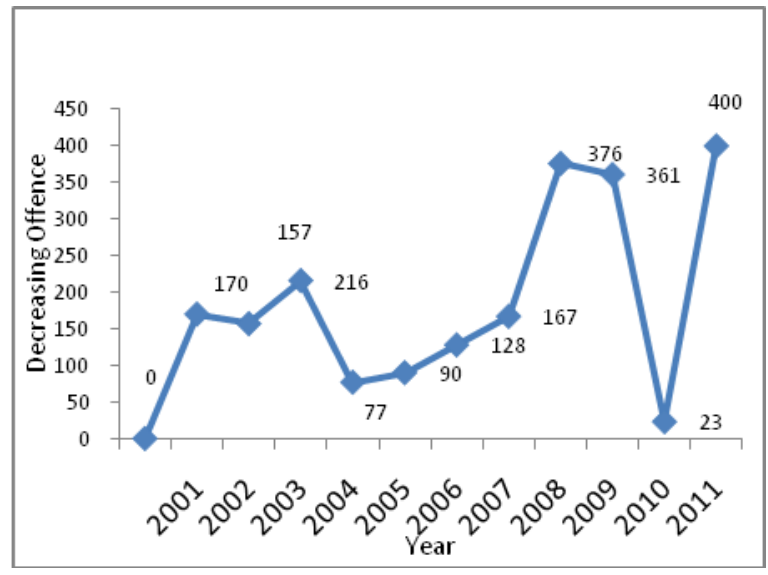

Fig 6. Trend of decreasing forest offences (Paul and Chowdhury, 2011)

Day by day the park management system is developed. The number of decreasing forest offence is increasing over time. In 2011 the maximum decrease of forest offences is 400, those forest offensive peoples around park area were trained under management authority and they were promoted as Community Forest Workers (CFWs). So the park management is develop gradually, it indicate the positive result for conservation of forest.

\section{Conclusion}

The proximity peoples of Madhupur National Park were received more forest products than the far peoples, they depend more on natural resources. The monthly income of local people were influenced by the park, the proximity peoples has more park income activity than off park income. The park management authority also provides various aid, opportunities, training and financial support for the local peoples, the adjacent people of park were more likely to receive that benefits because of staying close and they involve on forest conservation. The park management system were developed than past time, it involve people on community forestry, provide training for their self development and influence them for conserving forest. So it is gradually decreasing people park animosity.

\section{References}

Adams, W. M. and Infield, M. 2003. Who is on the Gorilla's Payroll? Claims on Tourist Revenue from a Ugandan National Park. World Development, 31 (1): 177-190.

Begum, R. 2011. People's livelihoods and involvement in co-management of Madhupur National Park, Bangladesh. USAID Contract No EPP-I-00-06-0000700.P: $156-170$

Blom, A. 2000. The Monetary Impact of Tourism on Protected Area Management and the Local Economy in Dzanga-Sangha (Central African Republic). Journal of Sustainable Tourism, 8 (3): 175-189.

Cavendish, W. 2000. Empirical irregularities in the poverty-environment relationship of rural households: evidence from Zimbabwe. World Development, 28: 1979-2000.

CEGIS (Center for Environmental and Geographic Information Services). 2008. Landuse/ Landcover and GIS database of Madhupur National Park. Dhaka, Bangladesh.

Falconer, J. and Arnold, J. E. M. 1989. Household Food Security and Forestry: An Analysis of Socio-economic Issues. Rome: FAO.

Kibirige, R. 2003. The socio-economic impacts of tourism on poor rural communities: the Mpembeni community, HluhluweUmfolozi Park, Kwazulu-Natal, South Africa. In Africa Insight [Online], 33(1). pp23-28

Mesozera and Janaki R. R. Alavalapati. 2004. Forest Dependency and its implications for Protected Areas Management: A case study from the Nyangwe Forest Reserve, Rwanda. Scandinavian Journal of Forest Research, 19 (suppl.4).

Mugisha, A. 2002. Evaluation of Community-based Conservation Approaches: Management of Protected Areas in Uganda. Florida, University of Florida.

Paul, A. R. and Chowdhury, S. A. 2011. Presentation on Paradigm Shift of Madhupur Forest Management 